\title{
Automatic Control of Haul Truck Travel Speed on Open Pits
}

\author{
MIODRAG I. ŽIKIĆ, University of Belgrade, \\ Professional paper \\ Technical Faculty in Bor, Bor \\ UDC: 629.365 \\ IVAN D. KUKOLJ, Montanuniversität Leoben, Leoben, Austria DOI: 10.5937/tehnika1804497Z \\ SA ̌́ S. STOJADINOVIĆ, University of Belgrade,
}

Technical Faculty in Bor, Bor

DEJAN I. TANIKIĆ, University of Belgrade,

Technical Faculty in Bor, Bor

Expanding raw materials production demands necessitates higher exploitation rates and capacities. Therefore, open pit mines resort to increasing their overall depth and hence introduce further machine related technical problems. Haul trucks experience intensified dynamic effects during traveling, resulting in a significant maintenance cost increase. The most influencing effects occur during the truck braking and stopping process, especially when heavily loaded. Current technical solutions in most haul truck configurations disregard plethora of these effects to lower their production cost.

The dynamic effects should be defined according to specific conditions on an open pit and applied for modifying currently employed systems for automatic truck speed control (ASC). It is the purpose of this paper to present the ASC system employed on the haul truck and key points for further modification and development.

Firstly, the paper presents basic aspects of the truck braking/stopping process. Secondly, a description of the BelAZ 75306 traction drive and braking systems is provided, followed by key features of the BelAZ 75306 ASC system. Finally, presented information is summarized, indicating flaws and recommendations for further improvement of the BelAZ 75306 ASC system employed on the open pit - ,,Veliki Krivelj “, Bor, Serbia.

Key words: Haul truck, ACS, travel speed, dynamic travel effects, braking/stopping process

\section{INTRODUCTION}

An increase of total mass and speed of heavy transport vehicles consequently necessitate an enhancement of related control systems to provide adequate safety and exploitation effectiveness and efficiency.

Raw materials play a crucial role in society's development, leading to a steeper increase of demands for related commodities in Europe [1]. To answer to such challenges, open pit mines resort to higher production rates, thus intensifying the employment of machinery and increasing the overall open-pit depth and width.With an increase of altitude differences and lengths of routes, haulage becomes the most complex

Author's address: Miodrag Žikić, University of Belgrade, Technical Faculty in Bor, Bor, Vojske Jugoslavije 12

e-mail: mzikic@rf.bor.ac.rs

Paper received: 20.06.2018.

Paper accepted: 25.07.2018. and costly production phase in an open pit [2]. Optimization of related cost functions originate from analysis of haulage technological parameters [3].

Increased payload and average travel speed can result in boosting of the haulage production capacity and significant overall cost reduction.However, this introduces problematic situations due to resulted dynamic events in the mechanical system of a truck, especially during braking and stopping. As the braking system fails to perform efficiently and effectively in all regimes, dynamic control of the travel speed becomes a necessity according to prevailing conditions.As the speed and mass related dynamic effects might induce severe consequences to both the machine and driver, haul trucks are equipped with an Automatic Speed Control (ASC) unit. ASC unit prevents the truck to exceed critical speed values, thus attaining ability to efficiently and safely brake and stop.

In theory, many parameters related to travelling conditions influence the value of the criticalspeed and 
the optimal speed range $[3,4]$. These parameters depend on travel conditions and related effects. Different stochastic variations of the parameter values take place for each travel related dynamic situation, thus raising the question: „What speed valuesto set for a specific hauling task and how to define the rules (influencing parameters, their weights and relations) for its alteration?" This is clearly a dynamic real-timeoptimization problem, which has to incorporate all the situation specific factors described throughout mentioned static and dynamic parameters.A dynamic control input should consist of real-time measured data related to the predetermined parameters, allowing the ACS unit to initiate an appropriate action and regulate the speed, thus preserving the safety of both the driverand the truck.

Such a system would have to be specially designed and configured for specific hauling tasks in an open pit mine. However, asthe price of custom-made haul trucks significantly exceeds the regular price value for the serial produced ones, most open pit mines decide their fleets to comprise of regular trucks. This introduces further truck configuration and production cycle problems, especially in the first truck exploitation period. Adaptation and reconfiguration process can last up to one year, leading to additional production and maintenance costs and drastic alterations of the hauling production cycle.

This paper provides an overview of the braking system and automatic speed control employed on haul trucks BelAZ 75306 (Figure 1) in the open pit mine „VelikiKrivelj“, Bor, Serbia. Following, the systems aspects of functioning in the exploitation environment are presented to point out major technical difficulties and problems. Finally, the paper provides a set of solutions and pointers for further development of these systems and hence the overall hauling production in the open pit.

\section{THE BRAKING SYSTEM EMPLOYED ON BELAZ 75306}

\subsection{General remarks on the haul truck braking/stopping process}

The term „braking“ describes the vehicle speed decreasing process governed by an internal machine system. The process is a result of controlled deceleration of a moving vehicle. The process can be referred to as „stopping“ if the final speed value is negligible in comparison to the ground base (movement reference frame). These processes in case of mechanical brakes function by ,forcing a stationary surface against that rotating", thus further converting (rotational) kinetic energy into heat due to friction [5]. These disc brake systems, however, have size, effectiveness and efficiency limits. In case of heavy vehicles, implementing such a deceleration usually includes a conversion of very high kinetic energy into heat, thus introducing a demand for an enhanced cooling system. For such a reason, heavy vehicles incorporate „retarder systems" for braking, whilst utilizing of frictional brakes is intended for braking at low speed (usually below $5 \mathrm{~km} / \mathrm{h}$, depending on the truck size and gross weight) and parking, when the vehicle has already stopped.

Retarder type and construction depends on the type of the drive. Basic retarder types are: engine, hydraulic, electric, exhaust and friction type [4].The main reason for the retarder application is the large overall truck mass resulting in high kinetic energy of a haul truck moving downhill or uphill [6]. Regardless of the type, the efficiency of a single retarder transmitter is proportional to the travel speed. Therefore, a retarder system has to incorporate multiple transmission steps for different speed levels[4]. These speed levels are arranged according to occurring travel conditions.

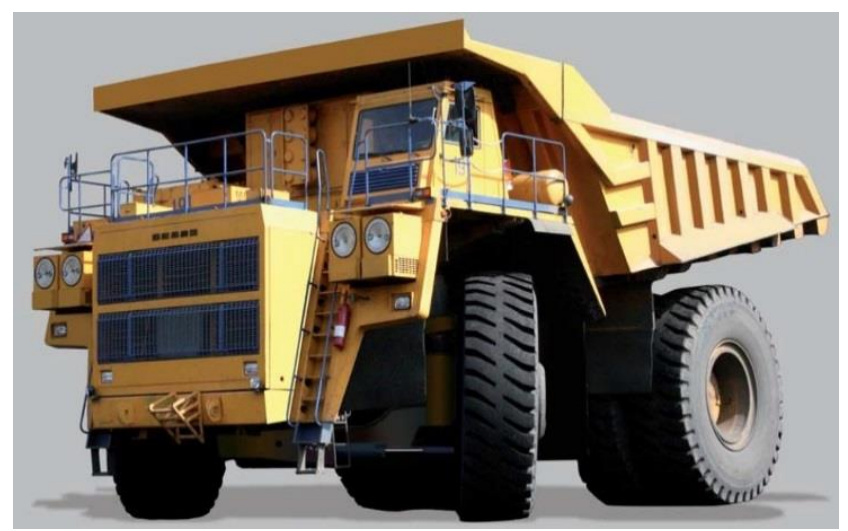

Figure 1 - BelAZ 75306 (www.belaz.minsk.by)

Thus, the travel conditions represent a combination of the parameters and effects that influence the braking process, such as [5-11]:

- Road conditions: longitudinal and transverse grade, road segment lengths and transition times, surface quality, visibility, etc.;

- Vehicle inclination: longitudinal-strike and transverse-dip;

- Vehicle declination;

- Regime of the vehicle movement: forward or reverse;

- Centre-of-gravity: position, alterations in respect to time and travel distance;

- Asymmetrical braking;

- Dynamic and static loading;

- Rimpull;

- Rolling resistance;

- Driver distraction and actions; 
- Atmospheric conditions;

- Tires and wheels;

- Truck geometry effects;

- Brake delay time;

- Engine control;

- Electrical system control;

- Stress/strain control and material fatigue monitoring for specific machine components.

Unfortunately, most of these parameters and effects are neglected during ASC system design and configuration, even during the initial test period in open pits. On the other hand, newly developed technologies encourage more intensive and more frequent ,intelligent" electronic control systems applications in automotive industry [12].

Recently, most of the heavy haul trucks (with above 100 tons payload) employ diesel-electric drives, that can be configured and designed for AC (Alternate
Current) or DC (Direct Current) traction motors. The $\mathrm{AC}$ traction motors industrial application is newer and promises higher performance and capabilities [5, 13]. Nevertheless, most open pits still employ haul trucks with DC traction motors. One of the reasons for this is the DC motor control flexibility and regime switching capability [14], allowing an effective and efficient application of electrodynamic braking.

\subsection{The belaz 75306 drive and breaking system}

Mining haul trucks can employ three types of drive train: mechanical drive, diesel-electrical with $\mathrm{AC}$ and diesel-electrical with DC electric drive [15].Most of the haul trucks in the open pit mine „Veliki Krivelj“ (e.g. BelAZ 75306) utilize a diesel-electric drive train. There are six major components in DC and AC electric drive trains: engine (diesel), generator (alternator), power converter(s), drive (wheel) motors, planetary gear sets (wheels) and retarding grid [5, 15].

Table 1. Basic BelAZ 75306 data (www.belaz.minsk.by)

\begin{tabular}{|c|c|}
\hline & 75306 \\
\hline \multicolumn{2}{|l|}{ Engine } \\
\hline Model & QSK 60-C \\
\hline Power rating, kW (hp) & $1716(2300)$ \\
\hline $\begin{array}{l}\text { Specific fuel consumption at } \\
\text { rated engine power, g/kW hr }\end{array}$ & 208 \\
\hline \multicolumn{2}{|c|}{ Electromechanical transmission } \\
\hline Alternator & СГД-101 \\
\hline Power, kW & 1400 \\
\hline Traction electric motor & ДK-724 \\
\hline Power, kW & 560 \\
\hline \multicolumn{2}{|l|}{ Weight } \\
\hline Payload capacity, kg & 220000 \\
\hline Unladen weight, kg & 156100 \\
\hline Gross weight, kg & 376100 \\
\hline
\end{tabular}

BelAZ 75306 (БелА3 JCS, 2010) haul truck (Table 1) utilizes a power source (aggregate) comprised of the diesel engine (Cummins QSK60, 1716 $\mathrm{kW})$ and alternator (СГД-101, $1400 \mathrm{~kW})$. The latter converts engine mechanical power into AC electrical power. Further on, this is power is converted into DC electrical power via controlled rectifier system(s) and provided for DC-drive motors. Next, the DC drive (wheel) motors convert received DC power into mechanical rotational power and transfer it to the wheels via planetary gear set. A bank of high-power electrical resistors, that constitutes the retarding grid, provides braking force by converting the electrical energy from the drive motors, whilst they work in the generator regime, into heat and dissipated by the cooling system. This occurs during the electrodynamic braking process when the drive motors act as power sources rather than power sinks. In return, the drive motors lose traction momentum, thus reducing the wheels rotation speed [15].

The haul truck includes the following braking systems: parking brake - friction type, which is governed by a hydraulic or pneumatic system and allowed only when the truck is not moving, service brake - friction type, which is not allowed during downhill movement, electrodynamic brake - electrical type equipped with ASC system (combined retarder system) and engine brake. In this case, the whole retarder system consists of the electrodynamic brake system, the engine brake system and related control systems. The service brake system is positioned on all four wheels and can be initiated only when the ASC system provides and 
information that the speed is below the set value $(5$ $\mathrm{km} / \mathrm{h})$.

This value can be altered by providing a manual data input to the electronic control system (SKAT).
Parking brake system comprises of active disc brakes installed only on the rear (drive) wheels. The employed brake systems provide the necessary truck deceleration in various situations.
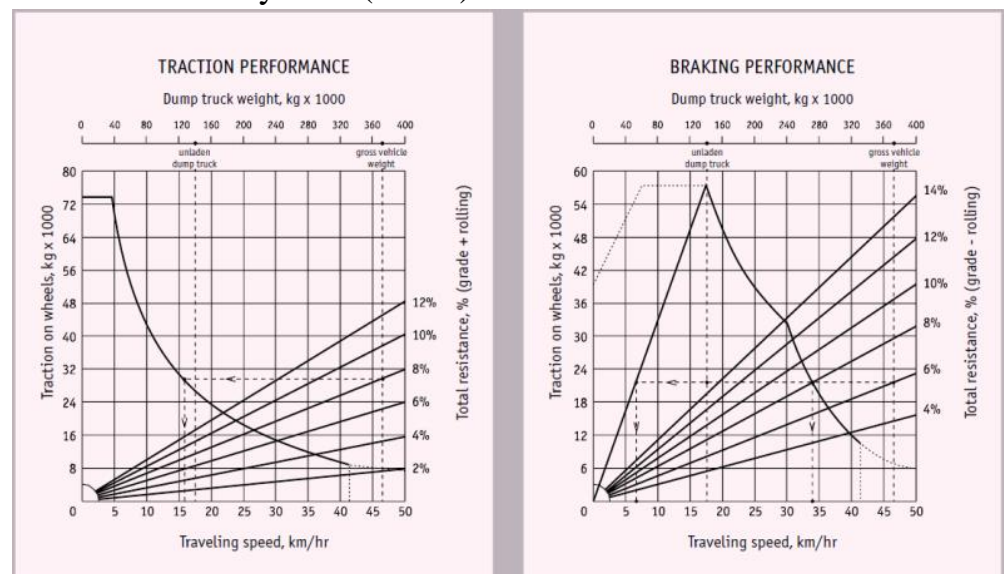

Figure 2 - The BelAZ 75306 traction and braking performance curves

The electrodynamic braking system is applied during the regular and forced electrodynamic braking. The processes are directly affected by the designed traction and brake performance (Figure 2).

The forced electrodynamic braking process includes additional drive motors excitation in the counter direction to develop the counter direction magnetic field in respect to the current direction of wheel rotation. This process can initiate various dynamic effects proportional to the acceleration gradient and therefore is applied only at low speed [16-18]. In a nutshell, the regular electrodynamic and engine braking can be presented throughout three levels. The first level of speed decrease is performed by diesel engine rotation speed (RPM) decrease (throttle release) resulting in the truck slowing down due to direct power transfer from the engine to the alternator.

The second level of braking is much more intensive and can be represented by an example of transition from the uphill to downhill movement. In this situation, electric drive motors shift to the generator regime, thus commencing to generate electrical energy proportional to the truck speed. Finally, the third level is reached upon initiating the electrodynamic brake. This alters the direction of excitation current in the stator circuit of the drive motors (Figure 3, pos. $5 \mathrm{~b}$ and 6b) by switching the primary contactors (Figure3, pos. 7), after which the set of secondary contactors (Figure 3 , pos. $8 \mathrm{a}$ and $8 \mathrm{~b}$ ) disconnect the drive line and connect the circuits with brake resistors (Figure 3, pos. $4 \mathrm{a}$ and 4b).

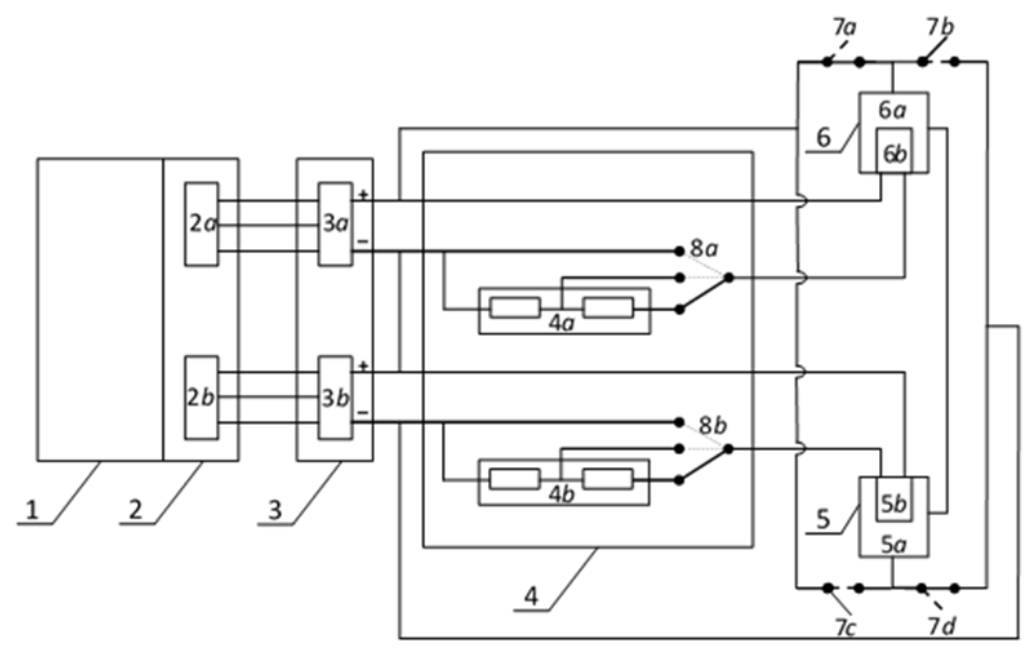

Figure 3 - Basic elements of diesel-electric drive and braking system 1 - Electric drive motor, 2 - Alternate current generators, 3 - Electric current rectifiers, 4 - Resistivity circuit, 5 - Left DC motor, 6 - Right DC motor, 7 -Current direction shifting switches system, 8-Contactors 


\section{AUTOMATIC SPEED CONTROL}

The ASC system employed on BelAZ 75306 haul trucks initiates the magnetic flux attenuation regime with (magnetic field attenuation) whilst the truck is moving forward and the speed limit regime (limiting the maximum wheel rotation speed). Initiation of the regimes depends on the ASC unit generated decision based on data acquired from speed sensors (implemented in all four wheels), sensors from the engine system and operating instructions from the central control unit (SUTEP). The ASC unit acts independently of the driver's actions (). In short, the simplified ASC unit operation follows the procedure:

1. The maximum travel speeds and ranges are defined and fed to ASC system either manually of by default during the ACS unit production,

2. Travel speed and engine rotation speed are continuously monitored and recorded,

3. Travel speed is continuously compared to predefined maximum values,

4. Once the travel speed equals or exceeds maximum value ASC unit is activated,

5. Upon activation, ASC first decreases the engine speed to high idle and then, if necessary, activates the electrodynamic brake resulting in speed decrease,

6. Once the travel speed decreases to a value below predefined maximum value, ASC system is deactivated,

7. Id the speed is not decreasing with acceptable rate ASC automatically increases the intensity of electrodynamic braking by increasing the resistance to the maximum and/or applying the field attenuation,

8 . If the speed information feedback indicate insufficient speed drop ASC increases the drive motors excitation current resulting in the maximum effect of electrodynamic braking,

9. When even the maximum electrodynamic braking has low effect ASC system automatically reacts and activates safety brakes as the last resort.

Complete travel data log and procedure history is stored in the real-time acquisition system incorporated inside the SUTEP data unit (,black box").The data can be accessed for production analysis, maintenance routine checks or in case of an accident caused by inadequate travel speed.

\section{SUMMARY}

Considering haulage, one of the most important mining phases, economic feasibility usually corresponds to high payloads. Increase in payload results in an increase of overall mass. However, mass increase result in the problem of achieving efficient and safe braking and stopping.

Basic BelAZ 75306 haul truck configuration includes the system for automatic speed control (ASC) that is programmed to follow certain operation procedures based on the real-time data acquired from rotation speed sensors on the wheels and engine. However, many dynamic parameters that influence truck movement are not measured and hence have no practical effect on the central control unit (SUTEP) and ASC system decision making. This means that a particular haul truck may function without any problems on one and experience frequent malfunctions on the other open pit route affected by the different conditions.

Pursuing the high hauling production capacity and rate on open pits corresponds to rapidly increasing the open pit depth and width, thus intensively altering the truck travelling conditions. This forced exploitation necessitates the ASC system adaptation to the altering travel conditions to avoid excessive maintenance cost increase. Thus, the ACS system should be designed as a modular, flexible, electronic control system capable of automatic measuring of the travel influencing parameters to improve the travel speed control. Therefore, the improved ASC system will be able to effectively and efficiently adjust the travel speed in realtime according to all conditions of significant influence.

Autonomy and versatility of the ASC system are gradually becoming the key modern haul truck features. Even though newly developed electronic and control technologies provide plausible answers to these demands (non-linear algorithms, neural networks, independent wireless sensors, fast Field Programmable Gate Array and microcontroller devices, etc.), related complex researches are yet to be conducted.

\section{REFERENCES}

[1] Vidal-Legaz B. The Raw Materials Scoreboard, European Innovation Partnership (EIP) on Raw Materials, GROW, European Union, 2016.

[2] Mahambetov D, Rakishev B, Samenov G. Efficient using of automobile transport for the deep open pit mines, Transport problems, Vol. 8, No. 3, pp. $25-$ 32, 2013.

[3] Žikić M. Definition of optimum road grade for truck haulage at surface mines, Master thesis, Technical faculty in Bor, 1993.

[4] Fancher P, O`Day J, Bunch H, Sayers M, Winkler C. Retarders for heavy vehicles: Evaluation of performance characteristics and in-service costs, 
Technical report, Highway safety research institute, The University of Michigan, Michigan, USA, 1981.

[5] Hustrulid et al. Open pit mine planning \& design (Volume 1 - Fundamentals), $3^{\text {rd }}$ edition, CRC Press, 2013.

[6] Soofastaei A, Aminossadati S, Arefi M, Kizil M. Development of a multi-layer perceptron artificial neural network model to determine haul trucks energy consumption, International Journal of Mining Science and Technology, Vol. 26, No. 2 ), pp. $285-93,2015$.

[7] McGarry P. Haul truck tires and open pit mining applications, Bachelor thesis, Queen's University Kingston, Ontario, Canada, 2007.

[8] Popović N. Naučne osnove projektovanja površinskih kopova, $2^{\text {nd }}$ edition, NIRO “Zajednica" NIŠRO „Oslobođenje“, Sarajevo, 1984.

[9] Stahl P, Donmez B, Jamieson G. A field study of haul truck operations in open pit mines, In: Proc. Human factors and ergonomic society 55th annual meeting, Las Vegas, USA, pp.1845 - 9, 19 - 23 September 2011.

[10]Santos-Reis M. de Oliviera Filho WL, E Oliviera, G Pena. Diagnosis about iron ore mine haul roads in the Quadrilátero Ferrífero - Itabira Complex case, $R$. Esc. Minas, Vol. 67, No. 4, 2014.
[11]Visser A T. Haul trucks make money, The journal of the Southern African Institute of mining and metallurgy, Vol. 115, No. 11, pp. 993 - 9, 2015.

[12]Leen G, Heffernan D. Expanding automotive electronic systems, Computer, Vol. 35, No. 1, pp. $88-$ 93, 2002.

[13]Jahns M, Blasko V. Recent advances in power electronics technology for industrial and traction machine drives, Proceedings of the IEEE, Vol. 89, No. 6, pp. $963-75,2001$.

[14]Wildy T. Electrical machines, drives, and power systems, $5^{\text {th }}$ edition, Prentice Hall, Upper Saddle River, New Jersey, USA, 2002.

[15]Humphrey J D, Wagner J D. Mechanical extraction, loading and hauling, in: Darling P. (Ed.), $3^{\text {rd }} S M E$ mining engineering handbook, SME, 2011.

[16]БелАЗ JSC: КарьерныйСамосвал БЕЛАЗ 75306. Устройство, эксплуатация и техническоеобслуживание, Belorussia, 2011.

[17]Internet source: www.belaz.minsk.by, 2016. (last accessed 19.06.2018.)

[18]БелА3 JSC: Руководство по эксплуатациииэсутэл-01, ООО "ВИСТ Групп", Moscow, 2010 .

\section{REZIME}

\section{AUTOMATSKA KONTROLA MAKSIMALNE BRZINE KRETANJA KAMIONA NA POVRŠINSKOM KOPOVIMA}

Povećana potražnja za proizvodnjom mineralnih sirovina uslovila je povećanje kapaciteta proizvodnje. Rezultat je povećanje dubina površinskih kopova što je za posledicu imalo tehničke probleme vezane za mehanizaciju. Kamioni se suočavaju sa pojačanim dinamičkim efektima u toku kretanja što rezultuje uvećanim troškovima održavanja. Najuticajniji efekti se javljaju prilikom procesa kočenja i zaustavljanja, posebno kod kamiona sa teretom. Sadašnja tehnička rešenja kod većine kamiona zanemaruju mnoštvo ovih efekata zbog smanjenja proizvodnih troškova.

Dinamički efekti se definišu u skladu sa specifičnim uslovima na površinskom kopu i treba da uslove izmenu na trenutno primenjenim sistemima za automatsku kontrolu brzine kretanja kamiona (ASC). Svrha ovog rada je da prikaže ASC sistem koji se koristi na rudarskim kamionima i ključne aspekte njegove modifikacije i daljeg razvoja.

Prvo, rad prikazuje osnovne aspekte procesa zaustavljanja i kočenja kod kamiona. Drugo, prikazan je opis sistema za vuču i kočenje kod BelAZ 75306 kamionakao i ključni parametri njegovog ASC sistema. Na kraju, prikazane informacije su sumirane kako bi se ukazalo na nedostatke i dale preporuke za dalje poboljšanje ASC sistema na BelAZ 75306 kamionima na površinskom kopu ,Veliki Krivelj“.

Ključne reči: kamioni kiperi, ACS, brzina kretanja, dinamički efekti, proces kočenja/zaustavljanja 